\title{
The Influence of Psychological Empowerment and Organizational Culture on Employee Satisfaction
}

\author{
Usep Deden Suherman ${ }^{1} *$ \\ Eeng Ahman ${ }^{2}$ \\ ${ }^{1,2}$ UPI Bandung Postgraduate School \\ Email: usepds@upi.edu*
}

\begin{abstract}
This study aims to determine and analyze the influence of psychological empowerment and organizational culture on job satisfaction of employees of PT. BRI Syariah Bandung City both partially and together. This research uses descriptive as well as verification methods. The study was conducted on 77 employees of PT. BRI Syariah Bandung City, Sampling is done using saturated sampling techniques. The data analysis technique used is multiple regression analysis. The findings of this study are that psychological empowerment and organizational culture partially or jointly have an impact on employee job satisfaction. Furthermore, the determinant value obtained was 0.883 , this means that psychological empowerment and organizational culture were able to explain job satisfaction worth $88.3 \%$. Meanwhile, $11.7 \%$ was caused by other factors.
\end{abstract}

Keywords: Psychological Empowerment, Organizational Culture, Job Satisfaction

\begin{abstract}
Abstrak
Penelitian ini bertujuan untuk mengetahui dan menganalisis pengaruh pemberdayaan psikologis dan budaya organisasi terhadap kepuasan kerja karyawan PT. BRI Syariah Kota Bandung baik secara parsial dan bersama-sama. Penelitian ini memakai metode descriptive serta verifikatif. Penelitian dilakukan pada 77 orang karyawan karyawan PT. BRI Syariah Kota Bandung, Pengambilan sampel dilakukan dengan memakai teknik sampling jenuh. Teknik analisis data yang dipakai ialah analisis regresi berganda. Temuan penelitian ini ialah bahwa pemberdayaan psikologis dan budaya organisasi secara parsial maupun bersama-sama mempunyai dampak terhadap kepuasan kerja karyawan. Selanjutnya, nilai determinan diperoleh senilai 0.883 , hal ini memberikan makna bahwa pemberdayaan psikologis dan budaya organisasi mampu menjelaskan kepuasan kerja senilai 88,3\%. Sementara itu, senilai $11,7 \%$ disebabkan oleh faktor lainnya.
\end{abstract}

Kata Kunci: Pemberdayaan Psikologis, Budaya Organisasi, Kepuasan kerja 


\section{INTRODUCTION}

HR as a potential driving force for an agency's activities, both human resources and non-human resources. These resources must influence each other, but HR plays a major role for the progress and achievement of an organization's goals. This is because the human factor is a problem that must be overcome by every organization, in order to maximize the use of existing resources which prioritizes the advancement of the potential for quality human resources in overcoming economic development and management demands that are more efficient in facing the new era of world industry and trade. practically without being teroterial. The development of the rate of economic growth and science which continues to develop and influence, resulting in increasingly complex problems and activities that are carried out and faced by the leadership of the organization and this will face the various characteristics of the wants and needs of their subordinates. The activities of employees should need to be aligned with organizational goals, in order to finally create an integrated movement in achieving an organizational goal.

Empowerment is a concept that companies need to build to increase employee job satisfaction. Companies apply empowerment as part of an effort to increase their competitive advantage in a competition. In general, the goal of empowerment is for the organization to respond quickly, flexibly, efficiently in accordance with the demands of customers / society / public and the market. Marked by a sense of satisfaction in the community it serves and on time in service. This is very much needed by a strong person who can provide excellent service

Empowerment is the subordinates' belief in their own skills, or the strength of the organization in facing obstacles and controlling problems (Behling \& McFillen, 2016). Empowerment is a management method used by organizations to increase organizational effectiveness (Spreitzer, 2016). With psychological empowerment, an employee will have security at work, because he can predict the career that will be passed until retirement. Psychological empowerment is behavior that is focused on employees so that employees can improve their abilities. With the existence of psychological empowerment, it will greatly help the organization achieve its goals because the employees have high abilities. Psychological empowerment can include encouragement, employee involvement, recognition or appreciation, and respect. By doing psychological empowerment, employees will feel themselves there and useful for the organization.

In a company organizational culture is a factor that can guide acting as an employee in the company. Organizational culture is a common understanding of various situations that occur within the organization. Mutually agreed values are used as a reference for members of the organization in responding to the situation that occurs. Organizational culture factors are often referred to as work environment factors, which create situational support for individual behavior in an institution. The work environment factor of an agency greatly affects the achievement of work results. If an employee working at the company feels that the organizational culture is suitable for him, it will affect job satisfaction.

Talking about job satisfaction cannot be separated from the factors that can affect employee job satisfaction. One of these factors is the organizational culture. Satisfaction is a feeling felt by employees, where what they want has been fulfilled. Stephen P. Robbins (2016: 99) explains that job satisfaction is a positive feeling about an employee's job in the form of an output of its characteristics. Job satisfaction, as stated by Riggio (2001) in Marselius (2017) is the main factor that affects employee life satisfaction because a lot of employee time is used for work. Therefore, Judge (2002) in Marselius (2017) sees a close relationship between job satisfaction, absences, work strikes, and turnover. Employees who get job satisfaction will do a good job on the other hand, employees who do not get job satisfaction will result in 
suboptimal performance so that job satisfaction is very important for companies to pay attention to in improving organizational performance.

BRI Syariah is the largest state-owned bank in Indonesia. Especially in the city of Bandung BRI Syariah has quite a lot of branch offices in the city of Bandung. BRI Syariah Bank in the city of Bandung in carrying out its activities cannot be separated from phenomena related to human resources. Such as the problem of psychological empowerment of employees, where the psychological empowerment of employees at PT. BRI Syariah has not been maximized so that the potential of employees cannot be maximally developed. For example, the company has not given awards commensurate with the achievements that have been given by its employees, the company does not provide employee morale to achieve the expected work performance and the company does not involve employees in work that is essential for the progress of the company. To create conditions that can empower employees psychologically, someone who is able to influence or enable employees to work in accordance with what the organization expects is needed. Likewise, problems related to organizational culture, the applied organizational culture has not shown any significant changes so that changes are needed to improve the organizational culture which in turn can develop company performance. This means that the organizational culture at BRI Syariah is still not supportive towards increasing job satisfaction so it tends to be stagnant and does not change towards improving employee performance. Of course this affects the job satisfaction of employees who are not satisfied with these conditions. From the description above, the authors have an interest in carrying out research on the influence of psychological empowerment and organizational culture on job satisfaction of employees of PT. BRI Syariah Bandung City.

\section{LITERATUR REVIEW \\ Psychological Empowerment}

The word empowerment is defined as giving responsibility and authority to individuals in making decisions. Empowerment means the importance of freedom for individuals to behave and have responsibility for their behavior in accordance with the work in their lap. This means that someone will be able to act independently and take full responsibility. Carizon in Milwadani (2015) shows that empowerment is not also "empowering" someone but is a process in releasing someone from a rigid "environment" structure. This definition explains, the empowerment process prioritizes flexibility for someone to make decisions responsibly.

Empowerment is involving employees who really have a contribution. Empowerment is the authority to make decisions in certain areas of activity without having to be authorized by others (Luthans, 2015). Meanwhile, Straub (1989) in Sadarusman, 2016), explains that empowerment is giving autonomy, authority, trust, and motivating individuals to organizations in order to develop rules for job completion. Empowerment means giving responsibility and authority to employees in making decisions related to product development and decision making. Empowerment can also be interpreted as sharing information and knowledge with all employees which is used to provide understanding and support for institutional performance, reward institutional performance and provide flexibility to make decisions that have an impact on the institution (Ford (1995) in Sadarusman, 2016).

Empowerment is a tool to generate trust between employees and management. There are 2 characteristics of empowerment, employees are motivated to make their own decisions, and employees are not only given authority but are given resources in carrying out decision making based on their creativity and innovation. Thus, employee empowerment begins with being asked "what can be achieved by giving employees freedom in carrying out planning 
and decision making based on the work for which they are responsible (Wilberforce, 2019). Through empowerment, employees are given the ability and opportunities to plan, implement, and supervise the implementation of work plans that are the responsibility of employees or group responsibilities (Nangoi, 2017). In empowerment, employees need to be ensured that: (1) have sufficient knowledge in carrying out their responsibilities, (2) understand the vision expected by the institution, (3) have loyalty to the vision of the institution, and (4) use smart technologies in order to implement knowledge in making products and providing services for users.

Thomas \& Velthouse (2000) dalam (Okyireh \& Simpeh, 2016) have suggested an alternative view of empowerment that is differentiated between situational attributes, for example management practices with occupational cognition from these attributes, for example psychological empowerment. Conger and Kanungo (Spreitzer, 2016) explain that management practice is only a series of situations and that practice is not always successful in order to strengthen employee expectations without being equipped with psychological empowerment from the employee. Sharafat Khan (2017) explains that psychological empowerment is an effort to form employee self-confidence and develop employee skills. Khan (2017) describes the empowerment model as follows:

1. Desire

The first stage in the empowerment model is a willingness from management to authorize and involve employees.

2. Trust

Stage two is to build trust between management and employees. There is mutual trust among employees that a good situation can be created in order to exchange information and recommendations without fear.

3. Confident

The third stage in the empowerment process is to give confidence to employees by respecting the existing competencies of employees.

4. Credibility

The fourth stage is maintaining competence through rewards and developing a healthy work environment so as to create an organization that has high performance.

5. Accountabiliy

The stage in the empowerment process is the employee's responsibility to the existing authorities. This stage is a means of evaluating performance that must be completed and accountable to the existing authorities.

6. Communication

This stage is the last stage where open communication is desired in order to create understanding between employees and management. This openness can be realized by the existence of criticism and recommendations on the results and achievements carried out by employees.

Meanwhile, Conger and Kanungo (Spreitzer, 2016) explain that psychological empowerment is a motivational concept of self-fulfillment, more specifically it can be expressed as an increase in intrinsic task motivation which is manifested in a series of cognitions that reflect individual orientation to realized work roles. in four dimensions: meaning, competence, self-determination, and impact.

\section{Organizational Culture}

Culture as a system and values that are adopted and developed in organizations that guide the behavior of organizational members. These values are the dominant values that are mutually agreed upon in the organization, forming an order of activities that culminate in the situational formation of an organization. The understanding of theoretical organizational 
culture put forward by Wood and Chapman (2017: 435) suggests that organizational culture is an understanding of the values and beliefs developed in the organization or sub-unit, which directs the behavior of organizational members. Furthermore, according to Wood, and Chapman (2017: 448) related to organizational culture is the right way to perceive, think and feel in relation to a social system. Organizational culture is a set of policies and rules that are part of normative control within the organization which can be seen in daily activities. In line with that, Vijay Sathe in Kreitner and Kinicki (2016: 83-84) states that organizational culture is a shared understanding of something important which is manifested in words spoken together, work carried out together and feelings that are shared.

Organizational culture is a common understanding of various situations that occur within the organization. Mutually agreed values are used as a reference for members of the organization in responding to the situation that occurs. Strengthening the results of this study, Edgar H. Schein (2000) in Luthan (2016: 124) conceptualizes organizational culture as "a pattern of basic assumptions, values and beliefs, as well as artifacts and creations that can direct organizational behavior". This opinion shows that organizational culture is basic assumptions, values, beliefs, artifacts and creations, which are able to direct the organization and its members to behave towards the situation at hand. The strength and weakness of organizational culture is shown by the extent to which primary values are intensively held, widely embraced, and clearly socialized among organizational members (Robbins, 2016).

Charles B. Handy (2001, in Yio Cheki, 2001 in Kusnendi, 2016) on the basis of organizational characteristics, there are 4 generic types of organizational culture, namely:

1) Apollo type. This type is characterized by high formalization and centralization. The salient characteristic of this type of organizational culture is that all tasks are organized systematically through several steps, are routine, result oriented. The highest power is concentrated in the hands of one person or group, therefore decisions are centralized.

2) Zeus type. This type is characterized by low formalization, high centralization. The organizational culture has no rules and no steps, but the highest power is concentrated in an individual or group like a spider in the middle of its network.

3) Athena type. This type is characterized by high formalization, low centralization. Organizational culture like this exists in many work groups organized for work with very independent work methods but closely related to measures and regulations.

4) Dionysus type. This type is characterized by low formalization and centralization. This kind of culture is very decentralized and tends to be informal.

\section{Job Satisfaction}

According to Robbins (2016) job satisfaction is the general attitude of an individual to his job. Job satisfaction is an attitude that influences work behavior. Wexley \& Yukl (2015) is job satisfaction related to employees' feelings about their work, attitudes to evaluate different aspects of tasks and describe their likes or dislikes based on experience. Furthermore, to measure job satisfaction, it is measured by going in and out, absenteeism, age, level of work and the size of the institution.

Employee satisfaction is a positive attitude to the work given by the organization where they work. It can be called the result of an evaluation on a task or work experience, with dimensions measured by the following scores (Gibson, Ivancevich and Donnelly, 2016):

a. Responsible, which is an aspect that cannot be separated or as a result of the ownership of authority and trust given to employees

b. Appreciation is a desire that comes from the need to be respected, appreciated, a sense of accomplishment, and respected by others

c. The job itself is a task that gives them the opportunity to use their skills, expertise at work and try to avoid boredom at work. 
d. Achievement, namely the award given to employees while performing tasks.

e. Promotion is the provision of opportunities for personal growth, various responsibilities, a high social position, and opportunities for development.

According to Robbins (2016: 85) there are several consequences or responses to one's job dissatisfaction as said by experts, there are several possibilities, namely

a. Exit, namely the employee resigns in order to obtain another job.

b. Voice, is to improve conditions through conversations with institutions. Some of the ways that employees generally do now are peaceful demonstrations.

c. Neglect, namely opposing through engaging in destructive behavior.

d. Loyalty, namely the acceptance of what is going on.

\section{The effect of psychological empowerment on employee job satisfaction}

Holdsworth and Cartwright (2003) in (Spreitzer, 2016) examined the relationship between psychological empowerment and job satisfaction. The psychological empowerment developed by the company will indirectly lead to job satisfaction for the employees themselves so that psychological empowerment is very important for the company to increase employee performance. Laschinger et. al (2005) in (Spreitzer, 2016) also explained that psychological empowerment reduces feelings of fatigue, thereby increasing job satisfaction. Psychological empowerment also mediates the relationship between psychological climate and job satisfaction (Carless, 2016). Research from (Akbar, et al. 2011; Khera, 2015; Naeem, 2013) explains that psychological empowerment of employees has a positive and significant impact on job satisfaction. Therefore, psychological empowerment has a relationship with the level of employee job satisfaction.

\section{The influence of organizational culture on employee job satisfaction}

Organizational culture is a system that is implemented and implemented simultaneously in an organization. This can have a positive or negative impact on employee job satisfaction at the company. Robbins (2016: 36) explains that the main factors that provide job satisfaction are jobs that create opportunities to use skills, and feedback on how much work performance is, then the next factor is the employee's work situation, from the aspect of personal comfort or ease of carrying out work, it relates to the rules and standards set by the organization, meanwhile, the rules and standards are made from the organizational culture of the institution itself. Research conducted by Koesmono (2015) explains that organizational culture has an influence on job satisfaction. This means that a good organizational culture in accordance with the values held by employees will indirectly affect job satisfaction. Apart from that, the results of research from Sinuhaji (2016) state the same thing that organizational culture has a positive influence on increasing employee job satisfaction. 


\section{Framework}

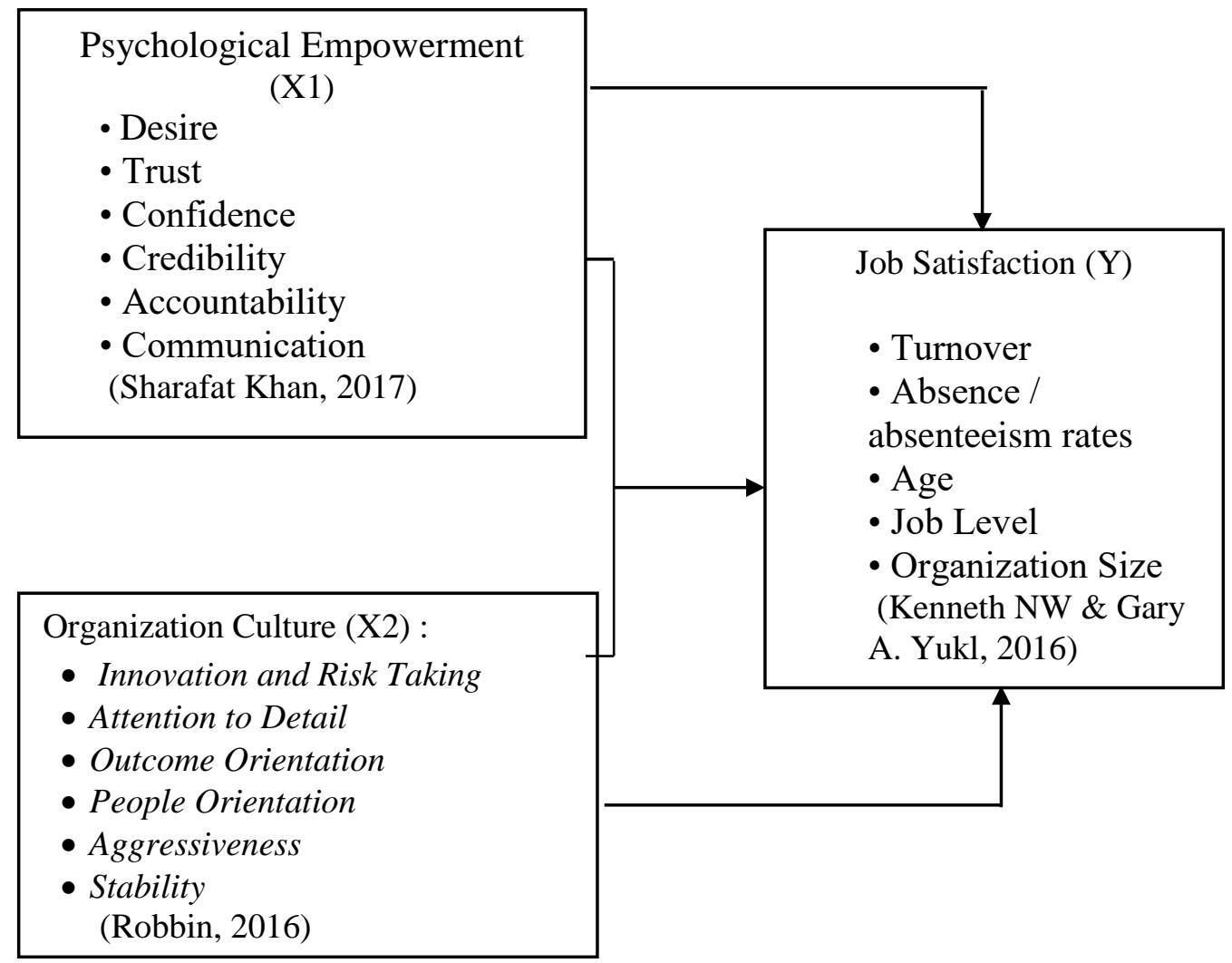

Figure 1 Research Model

\section{METHODS}

The approach used in this research is a survey approach. The survey method is a research method used in order to obtain facts from the phenomena in the field and obtain information that really exists (Nazir, 2017). This research is classified as descriptive and verification research. Descriptive research is research whose goal is to get a description of the characteristics of a variable. Meanwhile, in verification research, the researcher wants to test the truth of the hypothesis by collecting data in the field (Arikunto, 2019: 9). Meanwhile, verification research is a type of research whose aim is to determine the relationship between variables through hypothesis testing.

The variables used in this research are psychological empowerment and organizational culture which are independent variables and job satisfaction which are the dependent variables. Data collection techniques used were observation, interviews and questionnaires. The population in this study were 77 employees of BRI Syariah Bandung Branch, while the sample used was 77 employees of BRI Syariah Bandung Branch using a saturated sampling technique where all employees were taken as samples. Meanwhile, the data analysis method used is multiple regression analysis.

\section{RESULTS AND DISCUSSION}

This research uses multiple regression analysis techniques which aim to determine the relationship between independent variables and dependent variables. The independent variables in this research are psychological empowerment and organizational culture, while 
the dependent variable is job satisfaction. To find out the results of the multiple regression analysis are presented in the table below.

Table 1

Multiple Regression Results

\begin{tabular}{|c|c|c|c|c|c|c|}
\hline \multicolumn{2}{|c|}{ Model } & \multicolumn{2}{|c|}{$\begin{array}{c}\text { Unstandardized } \\
\text { Coefficients }\end{array}$} & \multirow{2}{*}{$\begin{array}{c}\begin{array}{c}\text { Standardized } \\
\text { Coefficients }\end{array} \\
\text { Beta }\end{array}$} & \multirow[t]{2}{*}{$\mathrm{t}$} & \multirow[t]{2}{*}{ Sig. } \\
\hline & & B & Std. Error & & & \\
\hline \multirow{3}{*}{1} & (Constant) & 4,260 & 1,507 & & 2,827 & ,004 \\
\hline & X1 &, 472 &, 043 & ,914 & 11,047 &, 000 \\
\hline & $\mathrm{X} 2$ & 026 & ,071 & 300 & 8,362 & 001 \\
\hline
\end{tabular}

a. Dependent Variable: Y

From the SPSS output above, it is obtained a multiple regression equation, namely:

$Y=4,260+0,472 X_{1}+0,026 X_{2}$

From this equation, 4.260 are independent variables, namely psychological empowerment and organizational culture have a positive correlation with job satisfaction. The constant value of job satisfaction of 4,260 indicates that the better job satisfaction will have an influence on psychological empowerment and organizational culture. Psychological empowerment has an effect on job satisfaction of 0.472 , while organizational culture has an effect on job satisfaction of 0.026 . From the description of the multiple regression model above, it shows that psychological empowerment and organizational culture have a positive value, meaning that it can increase job satisfaction.

\section{T test (partial)}

The test of the $t$ statistical value is a test of the significance of parameters that can contain correct predictions. This t statistic value illustrates the extent to which the influence of the independent variable on the dependent variable. If the t-count value is greater than the t-table value, it can be concluded that the variable has a significant effect or vice versa, if the $\mathrm{t}$-count value is smaller than the t-table value, it can be concluded that the variable has no significant effect. For more details, it can be reviewed in the table below.

Table 2

Partial Test ( $\mathrm{t}$ test)

\begin{tabular}{|c|c|c|c|c|c|c|}
\hline \multicolumn{2}{|c|}{ Model } & \multicolumn{2}{|c|}{$\begin{array}{l}\text { Unstandardized } \\
\text { Coefficients }\end{array}$} & \multirow{2}{*}{$\begin{array}{c}\begin{array}{c}\text { Standardized } \\
\text { Coefficients }\end{array} \\
\text { Beta }\end{array}$} & \multirow[t]{2}{*}{$\mathrm{t}$} & \multirow[t]{2}{*}{ Sig. } \\
\hline & & $\mathrm{B}$ & Std. Error & & & \\
\hline \multirow{3}{*}{1} & (Constant) & 4,260 & 1,507 & & 2,827 & 004 \\
\hline & $\mathrm{X} 1$ &, 472 &, 043 & ,914 & 11,047 &, 000 \\
\hline & $\mathrm{X} 2$ & 026 & 071 & 300 & 8,362 & 001 \\
\hline
\end{tabular}

a. Dependent Variable: $\mathrm{Y}$

From the partial test $(\mathrm{t})$, it is found that the psychological empowerment results have a probability (sig) value of $0.00<0.05$, so it can be concluded that Ho is rejected, $\mathrm{Ha}$ is accepted. Therefore, the psychological empowerment variable has a significant effect on employee job satisfaction. The results of this research are the same as research from Laschinger et. al (2001) also described psychological empowerment to reduce feelings of fatigue, thereby increasing job satisfaction. Psychological empowerment also mediates the relationship between psychological climate and job satisfaction (Carless, 2016). Research 
from Ida Maha Yani (2016) explains that psychological empowerment has a significant positive impact on job satisfaction. Employee psychological empowerment is a form of independence in which employees make decisions in order to provide assurance of maximum customer satisfaction, psychological empowerment is an extraordinary aspect in order to achieve success in business improvement and develop company performance (Akbar et al. 2011).

Meanwhile, the organizational culture variable has a probability value (sig) of 0.01 $<0.05$ so that $\mathrm{Ho}$ is rejected and $\mathrm{Ha}$ is accepted. Therefore, the organizational culture variable has a significant influence on job satisfaction. Therefore, the stronger the organizational culture in the institution, the employee job satisfaction will increase. The results of this research support the research results of Khan, et al (2011), Sabri, et al (2011), and Emami, et al (2012), which illustrate the evidence that there is a positive and significant correlation between organizational culture and job satisfaction. The results of this research also support the statement of Robbins (2016) explaining the main factors that provide job satisfaction are jobs that create opportunities to use skills, and feedback on how much work performance is, then the next factor is the employee's work situation, from the aspect of personal comfort or convenience in carrying out work, it relates to the rules and standards set by the organization, meanwhile, the rules and standards are made from the organizational culture of the agency itself.

It can be concluded that the $t$ test of the influence of psychological empowerment and organizational culture on job satisfaction obtained a significance value $<0.05$ so that the hypothesis that explains organizational culture has a significant effect on job satisfaction is partially accepted.

\section{Simultaneous Test (F)}

Meanwhile, simultaneous testing ( $\mathrm{F}$ test) is conducted to prove whether all the independent variables included in the regression model equation simultaneously have an influence on the dependent variable.

Table 3

Simultaneous Test $\mathbf{F}$

\begin{tabular}{llcrrrr}
\hline Model & & $\begin{array}{c}\text { Sum of } \\
\text { Squares }\end{array}$ & df & $\begin{array}{c}\text { Mean } \\
\text { Square }\end{array}$ & F & Sig. \\
\hline \multirow{3}{*}{1} & Regression & 2293,176 & 2 & 1146,588 & 280,452 &, $000^{b}$ \\
\cline { 2 - 7 } & Residual & 302,538 & 74 & 4,088 & & \\
\cline { 2 - 7 } & Total & 2595,714 & 72 & & & \\
\hline
\end{tabular}

a. Dependent Variable: $Y$

b. Predictors: (Constant), X2, X1

In the chart, the calculated $\mathrm{F}$ value is 280.452 and the significance value is 0.000 . After looking for Ftable then comparing it with the Fcount value. If the value of Fcount is greater than Ftable, then the alternative hypothesis is accepted, while Fcount is smaller than Ftable, then the null hypothesis is accepted, which means the alternative hypothesis is rejected. Ftable obtained by 3.159. Thus, the results of the study illustrate that the value of Fcount $>\mathrm{F}$ table is 280.452> 3.159 which means that $\mathrm{H} 0$ is rejected and $\mathrm{Ha}$ is accepted. Therefore, psychological empowerment and organizational culture together have an influence on employee job satisfaction. From the discussion on the $\mathrm{F}$ test, it is very clear that psychological empowerment and organizational culture can simultaneously increase employee job satisfaction. 


\section{Coefficient of Determination}

The coefficient of determination is used to determine the influence of all independent variables on the dependent variable. The coefficient of determination $(\mathrm{Kd})$ is the coefficient used and serves to determine the contribution of the psychological empowerment variable and organizational culture as independent variables to changes in employee job satisfaction as the dependent variable, through the known correlation coefficient $(\mathrm{R})$ and then multiplied by $100 \%$. Below is a table that explains the results of the coefficient of determination $(\mathrm{Kd})$ :

Table 4. The coefficient of determination

\begin{tabular}{llrrr}
\hline Model & $\mathrm{R}$ & R Square & Adjusted R Square & $\begin{array}{c}\text { Std. Error of the } \\
\text { Estimate }\end{array}$ \\
\hline 1 &, $940^{\mathrm{a}}$ &, 883 &, 880 & 2,02197 \\
\hline a. Predictors: (Constant), X2, X1 & & & \\
\hline
\end{tabular}

The research results show that simultaneously there is an influence of psychological empowerment and organizational culture on job satisfaction, which is $88.3 \%$, meaning that $88.3 \%$ of changes in employee job satisfaction at BRI Syariah are caused by psychological empowerment and organizational culture and $11.7 \%$ satisfaction. work is influenced by other aspects that are not found in the research model.

\section{CONCLUSION}

The results of research on the influence of psychological empowerment and organizational culture on job satisfaction of employees of PT. BRI Syariah Kota Bandung can be summarized as follows: 1) There is an effect of psychological empowerment on job satisfaction of employees of PT. BRI Syariah Bandung City. This shows that good psychological empowerment for employees can provide employee job satisfaction, 2) There is an influence of organizational culture on job satisfaction of employees of PT. BRI Syariah Bandung City. Therefore, organizational culture in accordance with employee personality can provide employee job satisfaction and 3) psychological empowerment and organizational culture have a simultaneous impact on employee job satisfaction. This illustrates that psychological empowerment and organizational culture together can provide job satisfaction for employees of PT. BRI Syariah Bandung City.

\section{REFERENCES}

Akbar, Syed Waqar., Muhamad Yousaf, Naeeem Ul Ha., dan Ahmed Imran Hujra. 2011. Impact of Employee Empowerment on Job Satisfaction: An Empirical Analysis of Pakistani Service Industry. Interdisciplinary journal of contemporary research in business, Vol 2, No 11, pp. 680-685.

Behling, O., \& McFillen. J.M., 2016. A Syncretical Model of Charismatic/ Transformational Leadership, Group \& Organizational Management, , 21 (2), 163-191.

Emami, Raheleh, Ebrahim Moradi, Durrishah Idrus and Dhaifallah Obaid Almutairi. 2012. "Investigating the Relationship between Organizational Learning Culture, Job Satisfaction and Turnover Intention in it SMEs". International Journal of Innovative Ideas (IJII). Vol. 12(1), April 2012, pp. 8 - 23

Gibson, James L., John M. Ivancevich, and James, H. Donnelly. 2016. Organisasi, Perilaku, Struktur, Proses, Terjemahan. Jakarta: Binarupa Aksara. 
Ida Maha yani. 2016. Pengaruh Pemberdayaan Dan Kepuasan Kerja Terhadap Komitmen Organisasional Guru Di Smk N 1 Mas Ubud. E-Jurnal Ekonomi dan Bisnis Universitas Udayana 5.12 (2016): 4177-4208

Khan, Verda, Asma Mariyum, Neelam Pasha \& Amna Hasnain. 2011. "Impact of Oraganization Culture on the Job Satisfaction of the Employees (Banking Sector of Pakistan)". European Journal of Economics, Finance and Administrative Sciences. Issue. 35, 2011, pp. 7-14

Khan, Sharafat, 2017, They Key to being a Leader Company: Empowerment, Journal Personality and Partisipation, p.44-45.

Khera, Aman. 2015. Impact of Employee Empowerment on Job Satisfaction: An Empirical Analysis of Banks in Chandigarh, (India). International Research Journal of Human Resources and Social Sciences, Vol 2, No 7, pp. 30-39.

Kenneth N. Wexley dan Gary A. Yukl, 2016, Organizational Behaviour and Personnel Psychology, Penerjemah Muh. Shobaruddin, Jakarta : Rineka Cipta

Koesmono. 2015. Pengaruh Budaya Organisasi Terhadap Motivasi Dan Kepuasan Kerja Serta Kinerja Karyawan Pada Sub Sektor Industri Pengolahan Kayu Skala Menengah Di Jawa Timur. Jurnal manajemen \& kewirausahaan, vol. 7, no. 2, september 2015: 171-188 Fakultas Ekonomi-Universitas Kristen Petra

Kreitner, Robert and Angelo Kinicki. 2016. Organization Behavior, Singapore : McGrawHill, Inc.

Kusnendi, 2016 Pengaruh Kompetensi, Komitmen dan Budaya Organisasi terhadap Aktualisasi Peran Manajer serta Efektivitas Organisasi (Survei pada Industri jasa BPR di Wilayah Kerja Kantor Bank Indonesia Bandung)”. Bandung

Laschinger, H., dan Finegan, J. 2005. Using empowerment to build trust and respect in the workplace: A strategy for addressing the nursing shortage. Nursing Economics, Vol 23, No 1, pp. 6.

Luthans, Fred. 2016. Organizational Behavior. 7-Ed. Mc.Graw-Hill International, New York.

Marselius \& Andarika, 2016, Hubungan Antara Persepsi Gaya Kepemimpinan Transformasional dan Transaksional dengan Kepuasan Kerja Karyawan, Jurnal psyche Vol. 1 No. 1, Desember 2016

Mildawani \& Susetyaning, T. 1999. Empowerment dan Penerapannya pada Individu. Majalah Ilmiah Humaniora PRANATA. Th. X. No. 1

Naeem, Almana. 2013. Impact of Employee Empowerment, Job Satisfaction and Organization Commitment on Customer Satisfaction. International Journal of Modern Business Issues of Global Market (IJMBIGM), Vol 1, No 1, pp. 28-38.

Nangoi. 2017. Pemberdayaan di Era Ekonomi Pengetahuan. Jakarta; PT. Grasiondo

Robbins, S. P. 2018. Perilaku Organisasi. Konsep, Kontroversi dan Aplikasi. Edisi Bahasa Indonesia. Jilid I. Jakarta: Prenhallindo.

Sabri, Pirsada S.U., Muhammad Ilyas \& Zahra Amjad. 2011. "Organizational Culture And Its Impact On The Job Satisfaction Of The University Teachers Of Lahore". International Journal of Business and Social Science. Vol.2, No. 24, 2011, pp 121128.

Sadarusman, Eka, 2016, Pemberdayaan: Sebuah Usaha Memotivasi Karyawan, Fokus Ekonomi, Vol. 3, No.2.

Sinuhaji, Effendi. 2016. Pengaruh Budaya Organisasi Terhadap Kepuasan Kerja Karyawan Pada Jasa Perhotelan (Studi Kasus di Garuda Plaza Hotel Medan). Bisnis Adminitrasi, Vol.2, No.1, Juni 2016

Spreitzer, 2016, Psycological Empowerment In the Workplace: Dimension, Measurement, and Validation. Academy of Management Journal, 38(5), 1442-1466. 
Thomas, K.W. \& Velthouse, B.A. 2016. Cognitive elements of empowerment: an 'interpretive' model of intrinsic task motivation. Academy of Management Review, 15(4), 666-81

Willberforce, T. 2019. Gaining a Competitive Advantage Through Employee Empowerment: Challenges and Strategies. Gadjah Mada International Journal of Business. Vol. 2, No. 1

Wood, Jack. Chapman, Judith. Wallace, Joseph. Zeffane, Rachid, M Zeffane. (2016). Organisational Behaviour: A Global Perspective. 3rd Edition, John Wiley \& Sons Australia, Ltd 